\title{
Front Matter: Volume 7209
}

, "Front Matter: Volume 7209," Proc. SPIE 7209, MEMS Adaptive Optics III, 720901 (7 March 2009); doi: 10.1117/12.828733

SPIE Event: SPIE MOEMS-MEMS: Micro- and Nanofabrication, 2009, San Jose, California, United States 


\section{PROCEEDINGS OF SPIE}

\section{MEMS Adaptive Optics III}

Scot S. Olivier

Thomas G. Bifano

Joel A. Kubby

Editors

27-29 January 2009

San Jose, California, United States

Sponsored by

SPIE

Symposium Cosponsors

Texas Instruments Inc. (United States)

Nanolnk, Inc. (United States)

The Photonics Center at Boston University (United States)

Ozen Engineering, Inc. (United States)

Conference Cosponsors

The Photonics Center at Boston University (United States)

National Science Foundation Science and Technology

Center for Adaptive Optics (United States)

Published by

SPIE

Volume 7209

Proceedings of SPIE, 0277-786X, v. 7209 
The papers included in this volume were part of the technical conference cited on the cover and title page. Papers were selected and subject to review by the editors and conference program committee. Some conference presentations may not be available for publication. The papers published in these proceedings reflect the work and thoughts of the authors and are published herein as submitted. The publisher is not responsible for the validity of the information or for any outcomes resulting from reliance thereon.

Please use the following format to cite material from this book:

Author(s), "Title of Paper," in MEMS Adaptive Optics III, edited by Scot S. Olivier, Thomas G. Bifano, Joel A. Kubby, Proceedings of SPIE Vol. 7209 (SPIE, Bellingham, WA, 2009) Article CID Number.

ISSN 0277-786X

ISBN 9780819474551

Published by

SPIE

P.O. Box 10, Bellingham, Washington 98227-0010 USA

Telephone +1 3606763290 (Pacific Time) · Fax +1 3606471445

SPIE.org

Copyright (c) 2009, Society of Photo-Optical Instrumentation Engineers

Copying of material in this book for internal or personal use, or for the internal or personal use of specific clients, beyond the fair use provisions granted by the U.S. Copyright Law is authorized by SPIE subject to payment of copying fees. The Transactional Reporting Service base fee for this volume is $\$ 18.00$ per article (or portion thereof), which should be paid directly to the Copyright Clearance Center (CCC), 222 Rosewood Drive, Danvers, MA 01923. Payment may also be made electronically through CCC Online at copyright.com. Other copying for republication, resale, advertising or promotion, or any form of systematic or multiple reproduction of any material in this book is prohibited except with permission in writing from the publisher. The CCC fee code is 0277-786X/09/\$18.00.

Printed in the United States of America.

Publication of record for individual papers is online in the SPIE Digital Library.

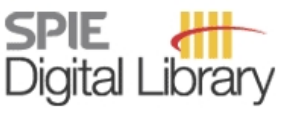

SPIEDigitalLibrary.org

Paper Numbering: Proceedings of SPIE follow an e-First publication model, with papers published first online and then in print and on CD-ROM. Papers are published as they are submitted and meet publication criteria. A unique, consistent, permanent citation identifier (CID) number is assigned to each article at the time of the first publication. Utilization of CIDs allows articles to be fully citable as soon they are published online, and connects the same identifier to all online, print, and electronic versions of the publication. SPIE uses a six-digit CID article numbering system in which:

- The first four digits correspond to the SPIE volume number.

- The last two digits indicate publication order within the volume using a Base 36 numbering system employing both numerals and letters. These two-number sets start with 00, 01, 02, 03, 04 , $05,06,07,08,09,0 A, 0 B \ldots$. OZ, followed by 10-1Z, 20-2Z, etc.

The CID number appears on each page of the manuscript. The complete citation is used on the first page, and an abbreviated version on subsequent pages. Numbers in the index correspond to the last two digits of the six-digit CID number. 


\section{Contents}

vii Conference Committee

ix The high versatility of silicon based micro-optical modulators (Plenary Paper) [7208-101]

H. Schenk, Fraunhofer Institute for Photonic Microsystems (Germany)

\section{SESSION 1 MEMS AO FOR BIO-IMAGING}

720903 Two-photon fluorescence microscopy with differential aberration imaging (Invited Paper) [7209-02]

K. K. Chu, A. Leray, T. G. Bifano, J. Mertz, Boston Univ. (United States)

720904 Optimum schemes for wavefront sensorless adaptive optics in microscopy (Invited Paper) [7209-03]

D. Débarre, B. Wang, T. Wilson, M. J. Booth, Univ. of Oxford (United Kingdom)

720905 Performance of a MEMS-based AO-OCT system using Fourier reconstruction [7209-04] J. W. Evans, Lawrence Livermore National Lab. (United States) and Univ. of California, Davis (United States); R. J. Zawadzki, Univ. of California, Davis (United States); S. Jones, S. Olivier, Lawrence Livermore National Lab. (United States); J. S. Werner, Univ. of California, Davis (United States)

720906 Implementation of a Shack-Hartmann wavefront sensor for the measurement of embryoinduced aberrations using fluorescent microscopy [7209-05]

O. Azucena, J. Kubby, J. Crest, J. Cao, W. Sullivan, Univ. of California, Santa Cruz (United States); P. Kner, Univ. of California, San Francisco (United States); D. Gavel, D. Dillon, Univ. of California, Santa Cruz (United States); S. Olivier, Lawrence Livermore National Lab. (United States)

\section{SESSION 2 MEMS AO FOR LASERS AND COMMUNICATIONS}

720907 Interferometric adaptive optics for high-power laser pointing, wavefront control, and phasing (Invited Paper) [7209-06]

K. L. Baker, Lawrence Livermore National Lab. (United States); E. A. Stappaerts, Lawrence Livermore National Lab. (United States) and Stappaerts Consulting, LLC (United States);

D. C. Homoelle, M. A. Henesian, E. S. Bliss, C. W. Siders, C. P. J. Barty, Lawrence Livermore National Lab. (United States)

720908 Quantum control spectroscopy (QCS) with a micro-electro-mechanical-system (MEMS) (Invited Paper) [7209-07]

T. Buckup, J. Möhring, M. Motzkus, Philipps-Univ. Marburg (Germany)

720909 Using MEMS mirrors to pattern electrical forces [7209-27]

S. L. Neale, H.-Y. Hsu, J. K. Valley, A. Jamshidi, M. C. Wu, Univ. of California, Berkeley (United States) 
7209 OA MEMS for femtosecond pulse shaping applications [7209-08]

A. Rondi, J. Extermann, S. M. Weber, L. Bonacina, Univ. of Geneva (Switzerland);

J. D. Roslund, M. H. Roth, H. A. Rabitz, Princeton Univ. (United States); J.-P. Wolf, Univ. of

Geneva (Switzerland)

7209 OB Novel construction of a deformable mirror for laser beam shaping [7209-09]

C. Bruchmann, Friedrich Schiller Univ. of Jena (Germany) and Fraunhofer Institute for Applied Optics and Precision Engineering (Germany); R. Eberhardt, E. Beckert, T. Peschel, S. Gramens, Fraunhofer Institute for Applied Optics and Precision Engineering (Germany); S. E. Gebhardt, Fraunhofer Institute for Ceramic Technologies and Systems (Germany); A. Tünnermann, Friedrich Schiller Univ. of Jena (Germany) and Fraunhofer Institute for Applied Optics and Precision Engineering (Germany)

7209 OC Secure optical communication system utilizing deformable MEMS mirrors (Invited Paper) [7209-10]

L. Ziph-Schatzberg, Boston Univ. (United States); T. Bifano, Boston Univ. (United States) and Boston Micromachines Corp. (United States); S. Cornelissen, J. Stewart, Boston

Micromachines Corp. (United States); Z. Bleier, PLX Inc. (United States)

\section{SESSION 3 MEMS AO FOR ASTRONOMY}

7209 OE MEMS devices in future astronomical telescope adaptive optics instruments (Invited Paper) [7209-12]

D. Gavel, UCO/Lick Observatory, Univ. of California, Santa Cruz (United States)

7209 OF The Naval Research Laboratory MEM adaptive optics program (Invited Paper) [7209-13] S. R. Restaino, T. Martinez, J. R. Andrews, C. C. Wilcox, F. Santiago, Naval Research Lab. (United States); D. M. Payne, Narrascape, Inc. (United States)

7209 OG Demonstration of a symmetric dark hole with a stroke-minimizing correction algorithm [7209-14]

J. D. Kay, Princeton Univ. (United States); L. A. Pueyo, Jet Propulsion Lab. (United States); N. J. Kasdin, Princeton Univ. (United States)

7209 Ol Preliminary characterization of Boston Micromachines' 4096-actuator deformable mirror [7209-16]

A. Norton, J. W. Evans, D. Gavel, D. Dillon, UCO/Lick Observatory, Univ. of California, Santa Cruz (United States); D. Palmer, B. Macintosh, Lawrence Livermore National Lab. (United States); K. Morzinski, UCO/Lick Observatory, Univ. of California, Santa Cruz (United States); S. Cornelissen, Boston Micromachines Corp. (United States)

\section{SESSION 4 AO IN CHINA}

7209 0J Adaptive optics at the IOE, CAS (Invited Paper) [7209-18] W. Jiang, C. Rao, Y. Zhang, N. Ling, C. Guan, Institute of Optics and Electronics (China) 
7209 OK Design and analysis of repulsive electrostatic driven MEMS actuators (Invited Paper) [7209-19]

J. Yao, F. Hu, D. Cai, W. Jiang, Institute of Optics and Electronics (China)

7209 OL Scaling of the Iris AO segmented MEMS DM to larger arrays (Invited Paper) [7209-20] M. A. Helmbrecht, M. He, C. J. Kempf, Iris AO, Inc. (United States)

7209 OM Advanced optical coatings of a segmented MEMS DM [7209-21] M. A. Helmbrecht, M. He, Iris AO, Inc. (United States)

7209 ON Novel unimorph deformable mirror for solid state laser resonators [7209-22]

S. Verpoort, P. Welp, U. Wittrock, Muenster Univ. of Applied Sciences (Germany)

720900 Initial performance results for high-aspect ratio gold MEMS deformable mirrors [7209-23]

B. Fernández, J. Kubby, Univ. of California, Santa Cruz (United States)

\section{POSTER SESSION}

7209 OP Liquid crystal adaptive optics system for unpolarized light [7209-24]

D. Cai, Institute of Optics and Electronics (China) and Taiyuan Univ. of Technology (China);

J. Yao, W. Jiang, Institute of Optics and Electronics (China)

$72090 Q$ Optical efficiency of MEMS deformable mirror for adaptive optics [7209-25]

D. Cai, Institute of Optics and Electronics (China) and Taiyuan Univ. of Technology (China);

J. Yao, W. Jiang, Institute of Optics and Electronics (China)

Author Index 
Downloaded From: https://www.spiedigitallibrary.org/conference-proceedings-of-spie on 26 Apr 2023

Terms of Use: https://www.spiedigitallibrary.org/terms-of-use 


\title{
Conference Committee
}

\author{
Symposium Chair
}

Albert K. Henning, Nanolnk, Inc. (United States)

Symposium Cochair

Thomas J. Suleski, The University of North Carolina at Charlotte

(United States)

Conference Chairs

Scot S. Olivier, Lawrence Livermore National Laboratory (United States)

Thomas G. Bifano, Boston University (United States)

Joel A. Kubby, University of California, Santa Cruz (United States)

Program Committee

William D. Cowan, Sandia National Laboratories (United States)

Christopher J. Dainty, National University of Ireland, Galway (Ireland)

Donald T. Gavel, University of California Observatories (United States)

Andreas Gehner, Fraunhofer-Institut für Photonische Mikrosysteme (Germany)

Wenhan Jiang, Institute of Optics and Electronics (China)

Alexis V. Kudryashov, Moscow State Open University (Russian

Federation)

Sergio R. Restaino, Naval Research Laboratory (United States)

Ulrich Wittrock, Muenster University of Applied Sciences (Germany)

\section{Session Chairs}

1 MEMS AO for Bio-imaging

Joel A. Kubby, University of California, Santa Cruz (United States)

2 MEMS AO for Lasers and Communications

Scot S. Olivier, Lawrence Livermore National Laboratory (United States)

3 MEMS AO for Astronomy

Thomas G. Bifano, Boston University (United States)

$4 \quad$ AO in China

Scot S. Olivier, Lawrence Livermore National Laboratory (United States)

5 MEMS AO Devices

Donald T. Gavel, University of California Observatories (United States) 
Downloaded From: https://www.spiedigitallibrary.org/conference-proceedings-of-spie on 26 Apr 2023

Terms of Use: https://www.spiedigitallibrary.org/terms-of-use 